\title{
The impact of the ZIKA Virus on the reproductive health of Brazilian women, environmental racism and the action for Direct Control of Unconstitutionality (ADI) No. 5581
}

\author{
O Impacto do ZIKA Virus na saúde reprodutiva das mulheres brasileiras, racismo \\ ambiental e a Ação Direta de Inconstitucionalidade (ADI) $N^{\circ} 5581$
}

\author{
Alexandre Godoy Dotta ${ }^{1}$ \\ Pontifícia Universidade Católica do Paraná (Curitiba, Paraná, Brasil) \\ alexandre.dotta@pucpr.br \\ https://orcid.org/0000-0003-1781-1726 \\ Larissa Ribeiro Tomazoni ${ }^{2}$ \\ Centro Universitário Internacional (Curitiba, Paraná, Brasil) \\ lrtomazoni@gmail.com \\ https://orcid.org/0000-0002-6715-7542
}

Recebido: 02.05.2020

Aprovado: 22.05.2020

\begin{abstract}
Has the objective of identifying social vulnerabilities on the ZIKAV epidemic that occurred in Brazil in 2015. Search realize the main focuses of social vulnerability and possible impacts of the disease on policies for the promotion of women's reproductive health. Develops by means of analysis of the official reports of the Ministry of health of Brazil and of the data presented by the Brazilian Institute of geography and statistics (IBGE). Concludes by pointing to poverty and the lack of basic infrastructure services suitable for the main factor that caused the brazilian outbreak. Describes how the disease affected mostly the northeastern poor women. And weaves considerations environmental racism and the report by the action of unconstitutionality (ADIN
\end{abstract}

Como citar esse artigo: DOTTA, Alexandre Godoy; TOMAZONI, Larissa Ribeiro. The impact of the ZIKA Virus on the reproductive health of Brazilian women, environmental racism and the action for Direct Control of Unconstitutionality (ADI) No. 5581. Revista Brasileira de Pesquisa Jurídica, Avaré, v. 1, n. 2, p. 109-132, maio/ago. 2020.

* This article has been translated and revised by Vinícius Hsu Cleto, master's student at Uninter.

${ }^{1} \mathrm{PhD}$ in History and Policies of Brazilian Education. Studied Master in Education and Specialization in Administration with an emphasis on Quality Management. Has a Lato Sensu postgraduate degree in Higher Education Methodology and in Knowledge and Scientific Work Methodology, holds a Bachelor of Technology, a degree in Sociology and Padagogy, He is publisher of the International Journal of Digital Law and Professor in the Graduate Program in Digital Law. alexandre.dotta@pucpr.br

${ }^{2}$ Master's at Uninter. Postgraduate in Gender and Sexuality. Graduate in Law (Unibrasil). Researcher of the "Núcleo de Estudos Filosóficos" (NEFIL/UFPR). Researcher of the "Grupo de Estudos Jurisdição Constitucional Comparada: Método, Modelos e Diálogos (Uninter). Columnist for "Sala de Aula Criminal”. Email: 1rtomazoni@gmail.com. 
$5.581 / 2016$ ), notably on the protection and defense of reproductive rights, especially the right to abortion.

Keywords: social vulnerabilities; ZIKA Virus; Reproductive Rights; Women health.

\section{Resumo}

Este artigo tem como objetivo descrever uma perspectiva socioeconômica sobre o fenômeno ZIKAV e o impacto da epidemia na saúde reprodutiva das mulheres brasileiras. Busca demonstrar, por meio dos relatórios do Ministério da Saúde e dos dados do Instituto Brasileiro de Geografia e Estatística (IBGE) as disparidades sociais entre as regiões brasileiras. Aponta que a ausência de infraestrutura adequada foi uma das causas da epidemia que afetou majoritariamente as mulheres pobres. Analisa a ADI $\mathrm{n}^{\circ} 5581$ e a sua relação com a proteção e defesa dos direitos reprodutivos, em especial, o direito ao aborto.

Palavras-chave: Vulnerabilidade social; ZIKA Vírus; direitos reprodutivos; Saúde das mulheres.

\section{Introduction}

Microcephaly caused by the ZIKA virus is in the spotlight. Several newspapers, magazines, websites, internet forums, blogs, and television shows emphasized this health condition that constantly affected newborn children from diseased pregnant women. Apparently, the responsible was the ZIKAV, an arbovirus unknown to Brazil until recently.

Nonetheless, the media coverage focused on a biomedical perspective that neglected other relevant aspects concerning the ZIKAV, the transmission process, and the most impacted sectors of the populace. Diseases mostly spread by mosquitos are not egalitarian. In Brazil, they tend to affect the most impoverished areas, the ones without proper infrastructure, water supply, health assistance, and sex education.

The lack of adequate infrastructure significantly affects the poorest women who do not have access to sex education and contraceptive methods. The reality of these women combined with the problems brought by ZIKAV, such as microcephaly, led to litigation in the Federal Supreme Court in 2016, through ADI (action for direct control of unconstitutionality) $\mathrm{n}^{\circ} 5581$, which discusses the possibility of women interrupting gestation affected by the ZIKAV epidemic. ${ }^{3}$

\footnotetext{
${ }^{3}$ The data set for this research can be accessed on the website: Social Vulnerabilities Caused by Zika Virus Outbreak of 2015 in Brazil: Women's Health, Environmental Racism and Action of Unconstitutionality $\mathrm{N}^{\circ}$. 5.581. November 18, 2018. Available at SSRN: https://ssrn.com/abstract=3286649 or http://dx.doi.org/10.2139/ssrn.3286649
} 
This article aims to describe a socioeconomic perspective on the ZIKAV phenomenon. The Health Ministry reports are geographically analyzed. Selected bibliography studies the qualitative disparities among Brazil's regions. At the same time, it presents a summary of biological and medical consequences of the ZIKAV, though acknowledging that this description is insufficient to properly comprehend the virus and its impacts.

\section{The ZIKA Virus}

The congenital symptoms of the ZIKA virus, which include microcephaly and other modifications of the central nervous system, are based on class in Brazil, since poor, Northeastern women are the most affected people. ${ }^{4}$ Jeffrey Lesser and Uriel Kitron mention a saying which affirms that "mosquitos are democratic; they sting anyone regardless of class condition" crisis had very different impacts on different classes, social groups, and genders. In other words, the ZIKA virus is another indication of Brazil's persistent inequality, even though decades have gone by since re-democratization". ${ }^{6}$

Diseases spread by mosquitos disproportionately affect the poorest. The outbreak of the ZIKA virus epidemic was most intense in Brazil's Northeast, where a larger share of the population lacks minimum conditions and where "climatic conditions favor the propagation of mosquito-spread diseases, especially when compared to Brazil's South, richer and less warm."7

In February (2015), seven months after the World Cup, the Secretary for Health Vigilance, organ of the Health Ministry, began to survey registers of Undefined Exanthematic Syndromes occurrences in Brazil's Northeast; the ZIKA virus (ZIKAV) was among the several arbovirus that were investigated. ${ }^{8}$

\footnotetext{
${ }^{4}$ DINIZ, Debora. Vírus Zika e mulheres. Available in: http://www.scielo.br/pdf/csp/v32n5/1678-4464csp-32-05-e00046316.pdf Accessed on: 10 fev. 2018.

5 LESSER, Jeffrey. KITRON, Uriel. A geografia social do zika no Brasil. Available in: http://www.scielo.br/scielo.php?script=sci_arttext\&pid=S0103-40142016000300167 Accessed on: 01 fev. 2018.

${ }^{6}$ Idem.

${ }^{7}$ Idem.

8 Ministério da Saúde. Boletim Epidemiológico volume $46 \mathrm{n}^{\circ}$ 26-2015. Available in: http://portalms.saude.gov.br/boletins-epidemiologicosAccessed on: 06 fev.2018. "There are strong hypotheses about the origins of the arrival of the ZIKAV in Brazil: sometimes the World Championship of Va'a, (Polynesian canoeing, between the $12^{\text {th }}$ and the $17^{\text {th }}$ of August, 2014, in Rio de Janeiro)
} 
The ZIKA virus is a kind of RNA arbovirus, originally isolated from human beings in 1952, in Uganda, and, subsequently, in Nigeria (1954). In 1964, the first clinical case was documented and described as a mild headache accompanied by fever and muscle aches. Between 1952 and 1981, few registers attest ZIKA virus infections in African and Asian countries. In 2007, the virus was identified on the Yap Islands, in Micronesia, involving a limited range of people with no registers of deaths nor complications. ${ }^{9}$

In 2014, occurrences were reported in French Polynesia and in New Caledonia. Specifically, in French Polynesia, it was registered an uncommon growth of seventeen malformations of the central nervous system from fetuses and newborn babies. It happened concomitantly with a ZIKA virus outbreak. No pregnant woman reported signs of the disease, which suggests a possible asymptomatic infection. ${ }^{10}$ On the $29^{\text {th }}$ of April 2015, Doctors Gúbio Soares Campos and Sílvia Campos announced that the ZIKA virus was being spread in Brazil. Until then, this arbovirus was unknown in the Latin-American country; also, the disease related to it was ignored. ${ }^{11}$

The ZIKA virus can infect people from both sexes and from all ages. It is an acute febrile illness; however, just $20 \%$ of the affected patients are esteemed to suffer from symptoms. There is no specific treatment, and symptoms are mild and short-lived. Infection in humans is mainly disseminated by the Aedes aegypti mosquito; after this first stage, nonetheless, it can be spread through sexual relations or through childbirth. ${ }^{12}$

sometimes FIFA World Cup (between the $12^{\text {th }}$ and the $14^{\text {th }}$ of July, 2014 in 12 different Brazilian states). As if it was not enough for sports competitions, there is a third hypothesis, little known, that the FIFA Confederations Cup (between the $15^{\text {th }}$ and the $30^{\text {th }}$ of July, 2013) had brought the ZIKAV a year before the first official notification of Zika presence in Brazil. (...) In order to test which event was responsible for the ZIKAV arrival in Brazil, researchers analyzed the DNA sequence of the virus. It was not the same lineage of the African pattern (Uganda, 1974), but actually it came from the Asian branch. Ignoring the "zero patient" - in other words, the first diseased person to bring the virus to Brazil -, but identifying the kind of virus, scientists prefer to think of the Confederations Cup or the World Championship of Canoeing, since those two events had athletes from French Polynesia." In: DINIZ, Debora. Zika: do sertão nordestino à ameaça global. Rio de Janeiro: Civilização Brasileira, 2016.p.3334.

${ }^{9}$ DREZETT, Jefferson; GOLLOP, Thomaz Rafael. O vírus Zika: uma nova e grave ameaça para a saúde reprodutiva das mulheres. Available in: http://recli.elsevier.es/pt/o-virus-zika-umanova/articulo/S1413208716300243/ Accessed on: 01 fev.2018.

${ }^{10}$ Idem.

${ }^{11}$ CARVALHO, Layla Pedreira. Vírus Zika e Direitos Reprodutivos: entre as políticas transnacionais, as nacionais a ações locais. Available in: https://portalseer.ufba.br/index.php/cadgendiv/article/view/22030/14756 Access on: 01 fev.2018.

12 DREZETT, Jefferson; GOLLOP, Thomaz Rafael. Op.cit. "Sexual transmission- Zika virus can be transmitted through sexual intercourse. This is of concern due to an association between Zika virus infection and adverse pregnancy and fetal outcomes. For regions with active transmission of Zika virus, 
Aedes aegypti is particularly well-adapted to the urban environment, where there is a huge concentration of human beings. Furthermore, urban spaces present ideal conditions for reproduction, since artificial recipients such as water tanks, buckets, and tires are common. ${ }^{13}$ Although sexual and vertical transmissions of the ZIKAV were reported, the most usual mode of transmission happens through vectors. ${ }^{14}$

Throughout 2014 and 2015, doctors used to believe that zika-virus affected patients were actually under symptoms of allergy. The illness has rapidly spread through Brazil's northeastern backlands. It caused a sharp rise in the number of microcephaly occurrences in babies. It was just in September and in November (2015) that the relationship between pregnant women infected by the ZIKAV and babies born with microcephaly was scientifically proved. Studies performed by Adriana Melo and Melania Amorim investigated pregnant and parturient women in Paraíba and in Pernambuco. ${ }^{15}$

The virus was identified through amniocentesis tests applied to women affected by the symptoms, which indicated intrauterine transmission of the infection. ZIKA virus has quickly become a grave public health issue due to its association with the rise of microcephaly occurrences in newborn babies of infected expectant mothers. ${ }^{16}$ Géssica

all people with Zika virus infection and their sexual partners (particularly pregnant women) should receive information about the risks of sexual transmission of Zika virus. WHO recommends that sexually active men and women be correctly counselled and offered a full range of contraceptive methods to be able to make an informed choice about whether and when to become pregnant in order to prevent possible adverse pregnancy and fetal outcomes. Women who have had unprotected sex and do not wish to become pregnant due to concerns about Zika virus infection should have ready access to emergency contraceptive services and counselling. Pregnant women should practice safer sex (including correct and consistent use of condoms) or abstain from sexual activity for at least the whole duration of the pregnancy. For regions with no active transmission of Zika virus, WHO recommends practising safer sex or abstinence for a period of six months for men and women who are returning from areas of active transmission to prevent Zika virus infection through sexual intercourse. Sexual partners of pregnant women, living in or returning from areas where local transmission of Zika virus occurs should practice safer sex or abstain from sexual activity throughout the pregnancy." In: WHO. Zika vírus. Available in: http://www.who.int/mediacentre/factsheets/zika/en/ Access on: 06 fev. 2018

${ }^{13}$ LESSER, Jeffrey. KITRON, Uriel. Op.cit.

14 Ministério da Saúde. Boletim Epidemiológico volume $46 \mathrm{n}^{\circ}$ 26-2015. Available in: http://portalms.saude.gov.br/boletins-epidemiologicosAccessed on: 06 fev.2018.

${ }^{15}$ CARVALHO, Layla Pedreira. Op.cit.

16 DREZETT, Jefferson; GOLLOP, Thomaz Rafael. Op.cit. "Nevertheless, exclusively associating the ZIKAV to microcephaly presents a limited perception of the problem. Those newborn babies, when subjected to rigorous testing, do not demonstrate only microcephaly, but also neural damage, severe optical modifications, loss of auditory acuity, hair excess and arthrogriposis. It sharply decreases child's standard of living, as well as normal development. Neural damages deserve special attention, because they are highly destructive: cerebral atrophy, white matter calcification, cerebellum calcification, caudate nucleus calcification, dysgenesis of the corpus callosum and of the vermix, expansion of the magna cistern. ". In: Idem.. 
Eduardo dos Santos and Maria da Conceição Alcântara Oliveira Matias, both from Juazeirinho (Paraíba), were the first women to donate amniotic fluid for researches which discovered that the ZIKA virus can go through the placenta. ${ }^{17}$

"Microcephaly is a congenital malformation that prevents the brain from developing adequately according to age and sex. Microcephaly can be caused by biological, genetic, environmental, and chemical factors". ${ }^{18}$ Because of microcephaly, the cephalic perimeter may present at least two standard deviations below average. This phenomenon can happen just after birth or during the baby's first years. ${ }^{19}$ The Health Ministry has been monitoring notifications and investigations related to microcephaly cases in Pernambuco since the $22^{\text {nd }}$ of October 2015. The first communiqué identified more than 26 cases of microcephaly in different regions. By the $17^{\text {th }}$ of November 2015 , 399 cases from seven northeastern States have been reported. Pernambuco leaded by $67,2 \%$, followed by Sergipe $(11,0 \%)$ and Rio Grande do Norte $(9,8 \%)^{20}$. By the $21^{\text {st }}$ of November 2015, 739 cases of possible microcephaly have been reported. Pernambuco was still leading $(65,9 \%)$, followed by Paraíba $(13,0 \%)$, and Sergipe $(7,3 \%)$.

Picture 1 demonstrates the spatial distribution of possible microcephaly cases that have been brought to the attention of the Health Ministry. It is noticeable that Brazil's Northeast concentrates the majority of situations.

${ }^{17}$ DINIZ, Debora. Zika: do sertão nordestino à ameaça global..., p.79-80. Géssica did more: even though she only had a few moments to hold her baby, she offered him for science. Still at the hospital, she authorized the medical team to take her dead son's organs for scientific research. (...) Géssica explains that she did not want "to be selfish regardless all other mothers without an answer". In: Ibidem, p. 80.

18 Boletim Epidemiológico volume $46 \mathrm{n}^{\circ}$ 34-2015. Available in: http://portalms.saude.gov.br/boletinsepidemiologicosAccessed on: 06 fev.2018.

${ }^{19}$ DREZETT, Jefferson; GOLLOP, Thomaz Rafael. Op.cit. "For genetic medicine, microcephaly may be divided in primary and secondary. Primary is more frequently caused by genetic abnormalities which interfere the growth of the cerebral cortex during the first months of fetal development. It is associated with chromosome syndromes and genetic/metabolic mutations. The commonest form is the vera microcephaly. There are no neurological modifications, except intellectual deficit. There are no skeletal abnormalities. There are some dominant autosomal mutations, some occurring in chromosome 8 , that can cause microcephaly. The same goes for modifications in chromosomes 13 and 21. On the other hand, secondary microcephaly has got perinatal causes, such as anoxia during birth, intraskull bleeding or obstetric trauma. It can derive from infections, subsequent to meningitis or encephalitis, caused by methylmercury, rubella, syphilis, chickenpox, toxoplasmosis or cytomegalovirus". In: Idem.

${ }^{20}$ The Report recommends: measures to reduce the presence of mosquitos that exert vector functions, such as abolishing recipients for stagnant water, adequate coverage of water supplies; closing doors and windows against mosquito; wearing pants and long-sleeved shirts; usage of insect repellents. Until further clarification of causes of microcephaly in Brazil's Northeast, women who desire to get pregnant must dialogue with trustworthy health teams, so as they can evaluate risks and information in order to take a conscious decision. In: Ministério da Saúde. Boletim Epidemiológico volume $46 \mathrm{n}^{\circ}$ 34-2015. Available in: http://portalms.saude.gov.br/boletins-epidemiologicosAccessed on: 06 fev.2018. 
Picture 1 - Spatial distribution of municipalities with occurrences of suspected microcephaly. Notifications taken until epidemological week 46, Brazil, 2015.

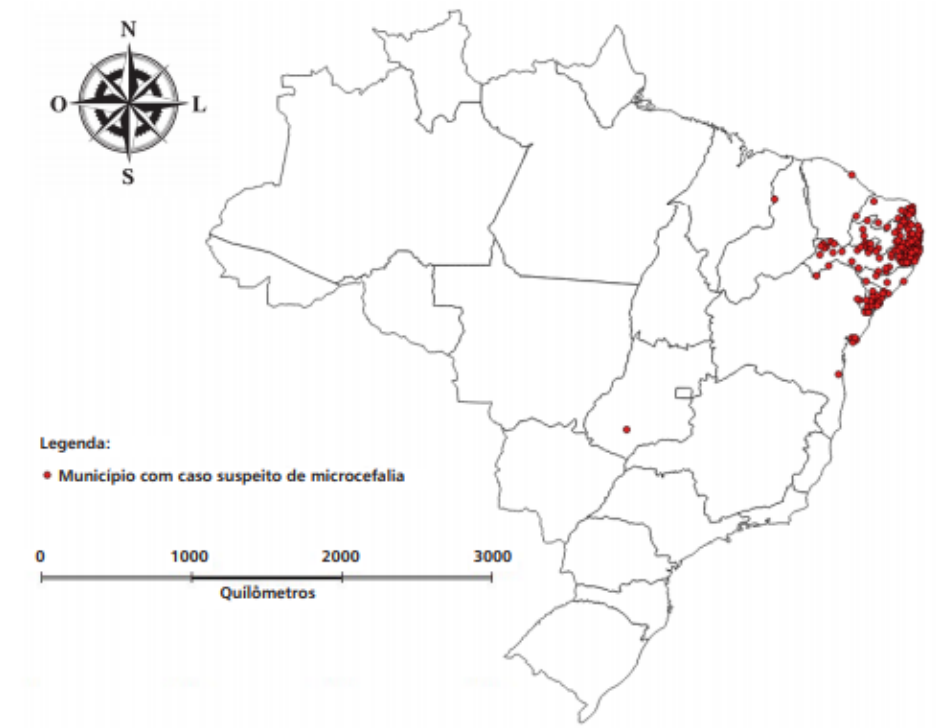

Source: Ministério da Saúde e Secretarias Estaduais de Saúde (atualizado em 21/11/2015). Boletim Epidemiológico volume $46 \mathrm{n}^{\circ}$ 37-2015

About the monitoring of microcephaly cases, by the $19^{\text {th }}$ of December 2015, 2.782 suspected cases of ZIKAV have been notified to the Health Ministry. Among the notified cases, 40 culminated in death. ${ }^{21}$ On the $26^{\text {th }}$ of December 2015 , the Health Ministry was notified of 2.975 suspected cases of microcephaly. Pernambuco was still leading the list (38,76\% of reports), followed by Paraíba (16\%), and Bahia $(9,11 \%)$. Among notifications, 37 deaths were registered. ${ }^{22}$ In July 2016, it was discovered that as children grew up, even if they had not presented symptoms of microcephaly when born, they would begin to agitate violently and to present visual, auditory, and motor difficulties. ${ }^{23}$

Epidemiological Report n. 41 (2017), which presents the epidemiological situation, as well as suspected deaths and alterations possibly related to the congenital infection, registered 14.916 suspected cases on the $14^{\text {th }}$ of November 2017. From the total amount, 3.014 cases $(20,2 \%)$ were confirmed and $287(1,9 \%)$ were classified as

\footnotetext{
21 Ministério da Saúde. Boletim Epidemiológico volume $46 \mathrm{n}^{\circ}$ 46-2015. Available in: http://portalms.saude.gov.br/boletins-epidemiologicosAccessed on: 06 fev.2018.

22 Ministério da Saúde. Boletim Epidemiológico volume $47 \quad \mathrm{n}^{\circ}$ 1-2016. Available in: http://portalms.saude.gov.br/boletins-epidemiologicosAccessed on: 06 fev.2018.

${ }^{23}$ CARVALHO, Layla Pedreira. Op.cit.
} 
probable. The scenario has not changed, since the majority of cases is still concentrated in Brazil's Northeast. The five most representative States are: Pernambuco (17\%), Bahia (16,2\%), São Paulo (8,9\%), Paraíba (7,5\%), and Rio de Janeiro (7,4\%). On notifications of newborn babies and children under monitoring, there were 533 confirmed cases out of 4.918 suspect cases. ${ }^{24}$ Epidemiological Report n. 49 (n.2-2018) compiles data from January 2017 to December, 2017. 2.160 probable cases affected pregnant women. Out of this total cipher, there were 949 confirmed cases. ${ }^{25}$

Laboratorial diagnosis, specific for the ZIKAV, is based upon the detection of the virus' RNA polymerase reaction chain through reverse transcriptase (RT-PCR). The viremic period lasts between three and seven days just after symptoms begin to appear. Nonetheless, most of the women, mainly the poorest, do not have access to this kind of examination, a situation that impedes the full acknowledgment of the problem from an epidemiological perspective. ${ }^{26}$

Only $18 \%$ of human infections are esteemed to result in clinical manifestations; it is, therefore, an asymptomatic infection. There is neither specific treatment nor injection that could prevent a ZIKAV infection. ${ }^{27}$ Investment in research and in fabrication of injections used against the ZIKAV will demand some time until these shots are made widely available for the general public. "Until then, preventive measures against the mosquito's sting is the alternative. "The war on Aedes aegypti is as necessary as it is complex. It involves mobilization of the population and providences from the public authorities. As if it was not enough, Aedes aegypti has been showing an extraordinary ability of biological adaptation that makes control and, specially, eradication, even more defiant." 28

24 Ministério da Saúde. Boletim Epidemiológico volume $48 \mathrm{n}^{\circ}$ 41-2017. Available in: http://portalms.saude.gov.br/boletins-epidemiologicosAccessed on: 06 fev.2018.

25 Ministério da Saúde. Boletim Epidemiológico volume $49 \mathrm{n}^{\circ}$ 2-2018. Available in: http://portalms.saude.gov.br/boletins-epidemiologicosAccessed on: 06 fev.2018.

${ }^{26}$ DREZETT, Jefferson; GOLLOP, Thomaz Rafael. Op.cit.

27 Ministério da Saúde. Boletim Epidemiológico volume $46 \mathrm{n}^{\circ}$ 26-2015. Available in: http://portalms.saude.gov.br/boletins-epidemiologicosAccessed on: 06 fev.2018.

28 DREZETT, Jefferson; GOLLOP, Thomaz Rafael. Op.cit. On a possible injection for the ZIKAV: OLIVEIRA, Monique. Vacina contra zika do Instituto Evandro Chagas deverá ser testada em humanos em 2018. Available in: https://g1.globo.com/bemestar/noticia/vacina-contra-zika-devera-sertestada-em-humanos-em-2018.ghtml Access on: 12 fev. 2018. Cientistas divulgam primeiros resultados de vacina contra zika. Available in: http:/g1.globo.com/jornalnacional/noticia/2017/04/cientistas-divulgam-primeiros-resultados-de-vacina-contra-zika.html Access on: 12 fev. 2018. Brasil firma parceria com EUA para testes de vacina contra zika em humanos. 
According to Debora Diniz, member of "Rede Nacional de Especialistas em ZIKA e Doenças Correlatas", from the Health Ministry, "there would be no epidemic such as the one developed in Brazil if this territory was not so propitious for quick dissemination: mosquitos, poor sanitation, and a deficient health policy against the disease." ${ }^{29}$

\section{Development, sanitation, and environmental racism}

In most big cities, epidemics caused by mosquitos affect each neighborhood in a different way; this variation is explained by distinct proliferation places and distinct concentration of people and insects. Inhabitants of the poorest neighborhoods are the ones most disproportionately impacted by illnesses ${ }^{30}$. In first place, this fact occurs due to a greater concentration of people living next to each other. In second place, those whose attribution is to formulate and implement public policies tend to come from the wealthiest strata of society ${ }^{31}$. Last but not least, the concentration of diseases at poor neighborhoods is correlated to irregular supplying of water, since the water pressure from pipes diminishes as it goes further away from distribution centers. At underprivileged neighborhoods, each family possesses its own water tank for water storage. Usually, those tanks are plastic recipients filled with water two or three times a week on the days when the neighborhood gets water supply. If those recipients are in bad shape or inappropriately closed, they may constitute reproduction havens for the Aedes aegypti. ${ }^{32}$

Leo Heller, environmental and sanitary engineer, demonstrates the relationship between health and sanitation, especially the role played by sanitation in the health situation of developing countries, which is strongly correlated to the socioeconomic model that is adopted; in this case, the vulnerable population is specifically composed

Available in: http://www.brasil.gov.br/saude/2017/09/brasil-firma-parceria-com-EUA-para-testes-devacina-contra-zika-em-humanos Access on: 12 fev. 2018.

${ }^{29}$ DINIZ, Debora. Zika: do sertão nordestino à ameaça global..., p.38.

${ }^{30}$ LESSER, Jeffrey. KITRON, Uriel. Op.cit.

${ }^{31}$ Idem.

32 Although many problems are easily solved (v.g., turning water recipientes upside down), other issues are more pressing. Waste collection, for example, is not regular at many neighborhoods in Brazil. Different items - such as plastic bags and disposable recipients - rapidly become reproductive havens after rain (...) Water tanks are also a possible source of problems. Though many families possess sophisticated recipients made of hard plastic (and, sometimes, made of aluminum), many others still use old water tanks, not properly closed, making it the ideal place for mosquito reproduction. In: Idem. 
by those excluded from the benefits of development. "Sanitation constitutes the control of all factors from human's physical environment that cause or may cause negative effects over the social, mental or environmental well-being." 33 In summary, risks derived from environmental insalubrity strongly affect populations from a lower socioeconomic status". ${ }^{34}$ Water supply insufficiency is verified in graphic 1 , available in the National Research on Basic Sanitation 2000/2008, whose author is the Instituto Brasileiro de Geografia e Estatística (IBGE).

Graphic 1 - Homes supplied with water from the general system, according to the Great Regions $2000 / 2008$

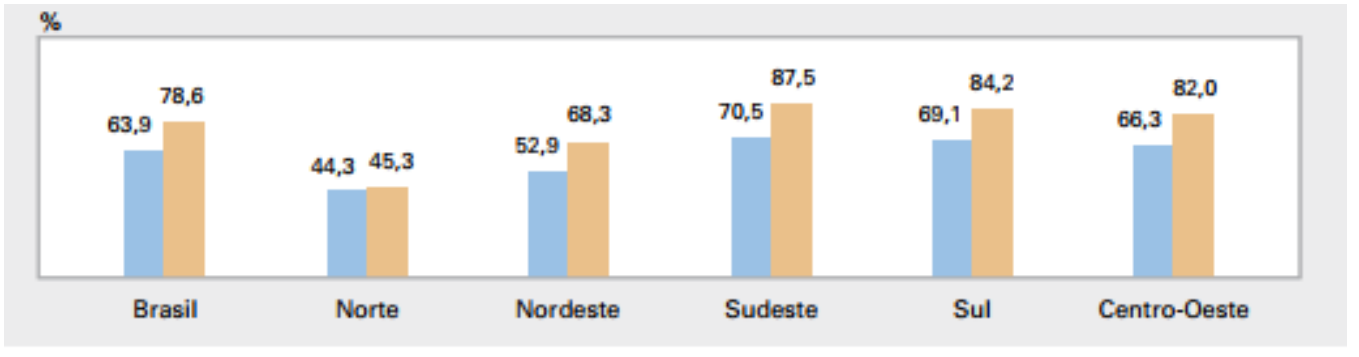

2000

Source: IBGE, Diretoria de Pesquisas, Coordenação de População e Indicadores Sociais, Pesquisa Nacional de Saneamento Básico 2000/2008.

Between 2000 and 2008, the registered water supply deficit was high. Near 12 million residences in Brazil did not have access to the general system. In some cities, due to water supply system inexistence, insufficiency or inefficiency, supplying may occur through different ways. ${ }^{35}$

There are 7,94 city halls where, regardless of the existence of the general supply system, distribution of water happens though alternative means. Water supply through peculiar ways reached more than 827 municipalities in Brazil, 14,9\% of the total amount.

\footnotetext{
${ }^{33}$ HELLER, Leo. Relação entre saúde e saneamento na perspectiva do desenvolvimento. Available in: http://www.scielo.br/pdf/csc/v3n2/7152.pdf Access on: 09 fev. 2018.

${ }^{34}$ Idem.

35 "Problem was most critical in Brazil's North, where 54,7\% of households were under that situation, followed the Brazil's Northeast (31,7\%), Center-West (18,0\%), South (15,8\%), and Southeast (12,5\%). In 11 out of the 27 states, the proportion of households without this public utility was equal or higher than 30\%. Rondônia (73,4\%), Acre $(64,2 \%)$, Pará $(63,6 \%)$, and Amapá $(59,4 \%)$ are the ones that suffered from it the most". In: IBGE, Diretoria de Pesquisas, Coordenação de População e Indicadores Sociais, Pesquisa Nacional de Saneamento Básico 2000/2008. Available in: https://biblioteca.ibge.gov.br/visualizacao/livros/liv45351.pdf Access on: 02 fev. 2018.
} 
Graphic 2 - Percentage of municipalities with alternative means of water supply, according to Great Regions - 2008

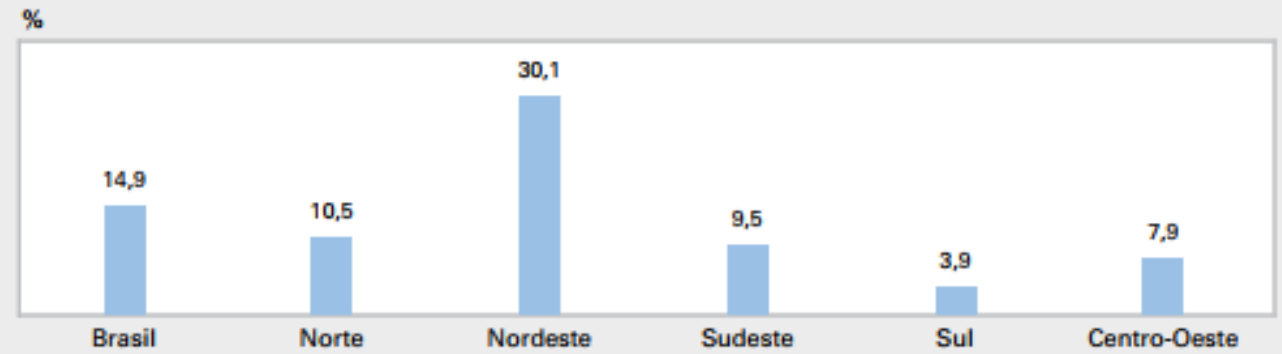

Source: IBGE, Diretoria de Pesquisas, Coordenação de População e Indicadores Sociais, Pesquisa Nacional de Saneamento Básico 2000/2008.

Brazil's Northeast $(30,1 \%)$ presents the greatest proportion of municipalities with occurrences of alternative means of water supply (different than the general system), more than two times the proportion observed in Brazil's average for other regions $(14,9 \%) .{ }^{36}$ Relationship between sanitation and development is crystal clear. Countries provided with better coverage of sanitation present healthier populations, an indicator, by itself, of the development level of the State. Human Development Index (HDI) "is comprised by three factors: life expectancy, knowledge (literacy rates and instruction) and standard of living (gross domestic product per capita)." ${ }^{37}$

The most affected states by the ZIKAV epidemics, and, subsequently, by microcephaly, were Pernambuco, Bahia, Paraíba, Sergipe e Rio Grande do Norte. Those states are among the eleven least developed in Brazil according to the Human Development Index. ${ }^{38}$ Moreover, those states, according to IBGE data on nominal household revenue per month, comprise populations living with less than R $\$ 937.00$ per month, a cipher that corresponds to Brazil's minimum wage in 2017.

\footnotetext{
36 "In this region, the spotlight goes to Piauí $(58,3 \%$ of municipalities), Ceará $(35,9 \%)$ and Maranhão $(30,4 \%)$. Considering the management and execution of water supply, most of it does not count with municipalities' participation. In 3,220 municipalities ( $58,2 \%$ of the ones that utilize the general system), the service was provided by other entities; city hall was responsible, exclusively or under partnership regime, in $2.311(41,8 \%)$ municipalities in Brazil" In: Idem.

${ }^{37}$ HELLER, Leo. Op.cit.

${ }^{38}$ Average HDI from Brazil's states. (Brazil 2017): 1 - Distrito Federal | HDI 0,839 2 - São Paulo | HDI 0,819 3 - Santa Catarina | HDI 0,813 4 - Paraná | HDI 0,790 5 - Rio Grande do Sul | HDI 0,779 6 - Rio de Janeiro | HDI 0,778 7 - Espírito Santo | HDI 0,771 8 - Minas Gerais | HDI 0,769 9 - Mato Grosso | HDI 0,767 10 - Mato Grosso do Sul | HDI 0,762 11 - Goiás | HDI 0,750 12 - Amapá | HDI 0,747 13 Tocantins | HDI 0,732 14 - Roraima | HDI 0,732 15 - Acre | HDI 0,719 16 - Rio Grande do Norte | HDI 0,717 17 - Ceará | HDI 0,716 18 - Rondônia | HDI 0,715 19 - Amazonas | HDI 0,709 20 - Pernambuco | HDI 0,709 21 - Bahia | HDI 0,703 22 - Paraíba | HDI 0,701 23 - Sergipe | HDI 0,681 24 - Maranhão | HDI 67825 - Piauí| HDI 0,678 26 - Pará | HDI 0,675 27 - Alagoas | HDI 0,667. In: HDI Médio dos Estados Brasileiros (Brasil 2017). Available in: http://www.geografiatotal.com.br/2017/09/HDIBRASIL.html Access on: 06 fev. 2018
} 
Sanitation and waste collection are almost universal services for urban dwellers, but those public utilities are less available for families headed by black men and women. Sanitation is the most unequal service, the one that reflects social inequality the most. Besides, these populations have to store water so as to face long periods without water coming out of taps. 39 "Disproportional exposition of black populations to contaminating environmental factors was defined, during the 1980s, as environmental racism." ${ }^{40}$ Environmental racism causes marginalized areas, mainly populated by poor black people, to suffer from lack of access to public utilities, a fact that impacts possibilities of lifting marginalized people out of poverty. Access restrictions to sanitation subject some groups to different epidemics along time. ${ }^{41}$

In Brazil, environmental racism can be comprehended as a recurring pattern of sanitation policies, since it is frequent that the same groups suffer from the lack of access to these services, a situation that tends to intensify health hazards to these populations, the most exposed to distinct vectors (such as the Aedes aegypti) that benefit from sanitation failures as means of reproduction. ${ }^{42}$

Environmental racism is one of the reasons that explain inequalities regarding access to sanitation. It is the bedrock of spreading diseases among vulnerable social groups and it reiterates the vicious circle of poverty and marginalization of the black population. The illnesses of pregnant black women caused by the ZIKAV epidemics is a sign of the persistent vulnerability that plagues those women ${ }^{43}$. "The investigation of diseases according to populational movements and geographic space cannot be separated of dynamics that are, a priori, political and social." 44

This perspective that considers political, social, and ideological dimensions is composed by four axes. "The first axis emphasizes the need of investigation of social and cultural processes through which ideas about global health are presented, interpreted, justified, legitimized and contested." The second axis is a critical appraisal that analyzes the consequences and concrete effects of practical definitions considered

\footnotetext{
${ }^{39}$ CARVALHO, Layla Pedreira. Op.cit.

${ }^{40}$ Idem.

${ }^{41}$ Idem.

42 Idem.

${ }^{43}$ Idem.

${ }^{44}$ NUNES, João; PIMENTA, Denise Nacif. Op.cit.
} 
"necessary" or "desirable". The third axis is the most important for this study. It refers to neglected zones:

\begin{abstract}
Negligence on health matters must be focused on its complexity: it is not only about invisibility or silence regarding some issues, but also, precisely, about the way some specific topics or groups become visible or invisible during this process. Negligence can be present even when too much attention is given to a specific topic, since the quality of this attention may be superficial, ephemeral or it may not consider relevant subjacent aspects. Recent Ebola epidemics is a good example of these dynamics. Media spectacle covering an epidemic does not always lead to structural problems resolutions. ${ }^{45}$
\end{abstract}

The ZIKAV epidemic received much mediatic attention, but certain aspects remained neglected due to technical and medical speeches directed to disease control; "among these neglected aspects are the issues of reproductive rights and abortion, maternal health, social determinants of the disease, infrastructural issues of health systems and city management, which enable mosquitos to spread and to reproduce". ${ }^{46}$ The fourth and last axis refers to diversity of individual experiences concerning illness and health. Due to determinants and due to social, economic and political conditions that generate and perpetuate the vector and the virus, ZIKA was classified as a "neglected disease" or "poor's disease". Definition of "negligence" can present a wide range, not only including diseases, but also social groups and populations. ${ }^{47}$

Some determinants are neglected when its impact on the susceptibility to some disease is not recognized or studied; by its turn, the neglected group is excluded from health care and/or under a vulnerable or risky position of contamination, which is the case of poor fertile-aged women. ${ }^{48}$ Solving structural issues (such as waste collection, sanitation, and water supply) is an urgent matter. ZIKA virus has been revealing Brazil's social disparities, such as SUS' insufficiencies, the persistence of structural problems that reflect the disadvantage and the vulnerability of specific populations, and other matters of social and economic relevance. ${ }^{49}$ Arboviruses immensely affect people neglected by public policies. "Regarding microcephaly, economic vulnerability plays an

\footnotetext{
${ }^{45}$ Idem.

${ }^{46}$ Idem.

${ }^{47}$ Since the 2000s, neglected diseases as Zika have been recognized, simultaneously, as a result and as a mechanism of poverty vicious circles, the so-called "poor diseases", "poverty diseases", or "rainforest poverty diseases". In: Idem.

${ }^{48}$ Idem.

${ }^{49}$ Idem.
} 
important role in the success of familial-planning strategies. Access to abortion and to contraceptive methods are conditioned to the economic situation". ${ }^{50}$

Hence, supposedly neutral and apolitical approaches, focused only on technical and biomedical instruments, tend to ignore existent inequalities. "The matter of poverty and vulnerability is, therefore, fundamental for understanding not only incidence and distribution of arboviruses (such as ZIKAV), but also availability or impossibility of reaction when confronted to possible adversities (such as microcephaly)". ${ }^{51}$

\section{Care protocol, response to microcephaly occurrences, and the action for direct control of unconstitutionality (ADI) $\mathrm{N}^{0} 5.581$}

Congenital syndrome related to the ZIKAV may cause the death of embryos, fetuses or newborn babies. If they survive, consequences can range from neurological damage to grave, permanent physical impairments. It is still unknown how many and in which cases infected women are going to witness vertical transmission and subsequent development of the congenital syndrome. There is no piece of information about the interval of time in which the virus is active inside infected women, representing risks of vertical transmission for future impregnations. Those uncertainties provoked by the epidemics, subject women to severe psychological suffering. ${ }^{52}$

The damage caused to these women and their future children is responsibility of Brazil's government, unable to suppress the mosquito that hosts the ZIKAV. Aedes aegypti was eradicated twice during the 1950s and during the $1970 \mathrm{~s}$, but it was able to come back due to the lack of public policies regarding sanitation, water supplying, and control of vectors, policies that mostly impact marginalized populations living in slums. ${ }^{53}$

\footnotetext{
${ }^{50}$ Idem.

${ }^{51}$ Idem.

52 Supremo Tribunal Federal. Ação Direta de Inconstitucionalidade no . 5581. Relatora Min. Carmen Lúcia. Available in: http://www.stf.jus.br/portal/processo/verProcessoPeca.asp?id=310227487\&tipoApp=.pdf. Access on: 01 fev. 2018

53 Idem.
} 
In March 2016, the Health Ministry issued the Care and Response Protocol Regarding the Occurrence of Microcephaly, which presents recommendations for caring, reproductive planning, and pre-natal accompanying. ${ }^{54}$

This Protocol fails to adequately cover the needs of poor black women who live in the most epidemics-affected areas in which access to contraceptive methods is difficult. This document should recognize the legal and socioeconomic restrictions that impact women's health. Though the Protocol acknowledges the importance of contraceptive methods against the epidemics, it seems to ignore the social inequalities that hinder women from accessing them and from getting informed about them. ${ }^{55}$

One of the most worrisome omissions of the Protocol is the abortion topic which is, nonetheless, a reality in Brazil. Criminalization of abortion does not impede its illegal occurrence. ${ }^{56}$ Statistics from the National Survey on Abortion (PNA) show that $22 \%$ of 35 to 39 -years-old women aborted at least once. Twenty-three percent of the women who aborted only reached the $4^{\text {th }}$ grade of elementary school. Forty-eight percent of these women took abortive medicines. ${ }^{57}$

Legal barriers against abortion particularly affect women who suffer from the worst socioeconomic conditions: black and brown women, young women, and women who dwell in rural areas or in marginalized urban areas. "Therefore, the omission of the Protocol regarding the risks of unsafe abortion is not only a failure that impedes the equal access to health, but also spotlights governmental negligence on taking measures to protect women's human rights, inside the context of the ZIKAV epidemics, hence violating norms of global health and international human rights standards." $" 58$

\footnotetext{
${ }^{54}$ BAUM, Paige. Et. al. Garantindo uma resposta do setor da saúde com foco nos direitos das mulheres afetadas pelo vírus zika. Available in: http://www.scielo.br/pdf/csp/v32n5/1678-4464-csp32-05-e00064416.pdf Access on: 01 fev. 2018.

${ }^{55} \mathrm{Idem}$.

${ }^{56}$ Idem.

${ }^{57}$ DINIZ, Débora; MEDEIROS, Marcelo. Aborto no Brasil: uma pesquisa domiciliar com técnica de urna. Available in: http://www.scielo.br/scielo.php?script=sci_arttext\&pid=S1413-81232010000700002 Access on: 06 jun. 2017.

${ }^{58} \mathrm{Idem}$. "Even though abortion is allowed in situations involving sexual violence, anencephaly, or threat to the woman's life, the Protocol does not cover the way health professionals must proceed in these former cases, nor it demands health professionals to inform women about the right to abort. Bearing in mind that 527,000 women are raped every year, it is fundamental that health professionals know the legal exception in cases of sexual violence. The contemporary degree of ignorance about criminal law regarding abortion is unacceptable. A national survey with obstetricians and gynecologists showed that less than half of them fully comprehended the national law on abortion. The Protocol, thus, loses an opportunity to teach professionals about legal abortion."
} 
Concomitantly to the scientific discoveries about the increase of cases registering neurological disorders and fetal malformation caused by the ZIKAV, a judicial case began in 2016. This action intended to assure the fundamental rights of women affected by the disease.

The Action for Direct Control of Unconstitutionality (ADI) $\mathrm{n}^{\circ} 5581$ that is processed at Brazil's Supreme Court (STF) was proposed by the National Association of Public Defenders (ANADEP) on the $24^{\text {th }}$ of August, 2016, and is related by Minister Carmen Lúcia. The aforementioned ADI also presents a petition based upon the disobedience of a fundamental precept (ADPF), in which Brazil's omission about the possibility of interrupting ZIKAV-affected gestations is discussed. The Argument of Disobedience of a Fundamental Precept intends to avoid or to repair a lesion to fundamental precepts caused by an act of the State. Reading ADI $n^{\circ} 5581$, the contested acts that are relevant to this research are:

The contested State's acts are: 02.1. omitting information about the state-ofthe-art medical knowledge on the ZIKAV, its uncertainties, risks of infection, and preventive methods; 02.2. omitting access to care and familial planning, including access to long-term reversible contraceptive methods, such as DIULNG, and the mosquito repellent; 02.4. omitting the literal and express possibility of interrupting pregnancy as a health public policy of the Brazilian State regarding impregnated women infected by the ZIKAV. 03. These omissions are expressed by the absolutely unsatisfactory public policies against the ZIKAV, which are formally framed by Instructions, Technical Norms and Protocols of the Federal Government. The omission is also expressed by the inexistence of funds allocated for the concretization of the necessary measures to be taken against the pernicious effects of the epidemics. As described above, the main documents are: a) Response Protocol Regarding the Occurrence of Microcephaly and/or Modifications the Central Nervous System (SNC); b) Protocol for the Implementation of Sentinel Unities for the ZIKAV; c) Care and Response Protocol Regarding the Occurrence of Microcephaly; d) Directives for Precocious Incentives For 0-3-years-old Children Suffering from Retarded Development of the Neuropsychomotor System Caused by Microcephaly; e) Act MS n ${ }^{\circ} .3$, dated $01 / 11 / 2016$, f) Joint Operational Instruction MS-MDS $\mathrm{n}^{\circ}$. 1, dated 02/25/2016; g) Inter-Ministerial Act $n^{\circ} .405$ dated 03/15/2006; and h) Joint Operational Instruction MS-MDS $n^{0}$. 2, dated 03/31/2006. 05. Firstly, it is emphasized that there is no other efficient means to abstractly repair the lesions. Regarding the four petitions in this ADPF, there is no intention to declare the constitutionality or the unconstitutionality of normative acts edited after the 1988 Constitution (ADI and ADC) or the omission of legislative act (ADO). Regarding three demands, insufficient public policies based upon secondary normative acts are questioned. Also, there is a demand asking for constitutional interpretation of articles 24, 124, 126, and 128 from 
Brazil's Criminal Code; in other words, from pre-constitutional legislation. Those topics are typically questioned through $\mathrm{ADPF}^{59}$

State's omission is established when the adopted public policies are insufficient to guarantee women's rights. It is a kind of unconstitutional behavior. ${ }^{60}$ The action points out that there were violations of the following fundamental precepts:

Human dignity (art. $1^{\circ}$, III, da CR), free development of personality, rights to freedom, to psychological and physical integrity (art. $5^{\circ}$, caput, CR), right to information (art. $5^{\circ}, \mathrm{XIV}$, da CR), protection of childhood and motherhood (art. $6^{\circ}$, da CR), right to health, right to disease prevention (arts. $6^{\circ}, 196 \mathrm{e}$ 198, II, da CR), right to social security (art. 203, da CR), right to family planning and to reproductive freedom (art. $226, \S 7^{\circ}$, da CR) and protection of persons with disabilities (art. 227, caput, $\S 1^{\circ}$, II, da CR). ${ }^{61}$

On the topic that asserts omission for not assuring contraceptive methods and repellents against the mosquito, it is argued that the Brazilian State was negligent by not conceiving or executing public policies focused on family planning and ZIKAVaffected women's reproductive health. Contraceptive methods and access to repellents against the Aedes aegypti should have been provided. ${ }^{62}$

The right to family planning, based upon article $226, \S 7^{\circ}$, Brazil's Federal Constitution, presupposes access to these methods and, in the case of the ZIKAV epidemics, "a public policy aiming at extensive contraceptive methods is fundamental, one which focuses on women within the reproductive age and on the most vulnerable population, with wide distribution of contraceptive methods." 63

\footnotetext{
${ }^{59}$ Supremo Tribunal Federal. Ação Direta de Inconstitucionalidade $\mathbf{n}^{\mathbf{0}} . \mathbf{5 5 8 1} \ldots$

${ }^{60}$ Brazil's Supreme Court jurisprudence asserts that: "If the State neglects the necessary measures to concretize the Constitution's precepts in order to make them effective, operative and executable, it consequently abstains itself from applying the Constitution; thus, it is a negative violation of the constitutional text. From this non facere or non prestare, there is unconstitutionality for omission, which may be total (no providence is taken) or partial (the measure taken by the State is insufficient) (...) State's omission - established by the negligence, at any length, to apply the constitutional impositions - must be considered an utmost grave political-juridical behavior, since inertia also means disobedience of the Constitution, offense of the rights based upon the text and, because there is a lack of concrete measures, the inapplicability of principles and postulates of the Fundamental Law (STF, Medida Cautelar na Ação Direta de Inconstitucionalidade no . 1439, Reporter Min. Celso de Mello, Judged on 05/22/1996, Published: DJ 30-05-2003)." In: Idem.

${ }^{61}$ Idem.

${ }^{62} \mathrm{Idem}$

${ }^{63}$ Idem. Art. 226, Federal Constitution. Family, society's base, has special protection of the State. (...) $\S$ $7^{\circ}$ Founded on the principles of human dignity and responsible paternity, family planning is a free decision of the couple, and it is a State's attribution the propitiation of educational and scientific resources for the exercise of this right, vetoed any coercing form taken by official or private institutions".
} 
According to the National Plan for Combating Microcephaly, the use of repellents is frequently cited as a preventive strategy; nonetheless, there was no free distribution of this product. "In times of public health crisis, mainly provoked by the ZIKAV, repellents are a basic prerequisite for a healthy gestation and, therefore, must be comprehended as a 'means of conception' which, according to article 9 from Federal law $n^{\circ} .9 .263 / 1996$ composes the right to family planning." ${ }^{64}$

Regarding Brazil's omission about the possibility of interrupting pregnancy as a public policy offered for ZIKAV-infected women, ANADEP demands that articles 124, 126, and 128, I-II of Brazil's Criminal Code are interpreted according to the 1988 Federal Constitution. ${ }^{65}$ The advisory opinion from the Global Health Justice Partnership (GHJP), from the Yale University, which is part of the ADI, highlights Brazil's omission regarding public policies about health reproduction:

Such as the HIV/AIDS epidemics, effectively combating ZIKAV will demand from the Brazilian government working within the diverse sociocultural context so as to evaluate the needs of vulnerable populations and so as to expand the health resources availability for them. The Protocol [of Health Care and Response to the Occurrence of Microcephaly] adequately recognizes the importance of the use of contraceptives; also, it recognizes the importance of men during pregnancy. However, it does not show a comprehensive understanding of the social context in order to adequately face the ZIKAV epidemics in a manner that offers support to Brazil's compromises with public health and human rights objectives. Specifically, the Protocol ignores the complex realities associated to women's reproductive decisions. It does not explain practical challenges that many individuals, especially poor women, face when they try to obtain contraceptive methods. Nor does it make any mention of abortion, legally available or not. To improve public health and human rights, the Protocol has to be based upon women's life experience instead of theoretic solutions. Furthermore, the exclusion of covering alternatives of health reproduction demonstrates once again that the Brazilian Protocol neglects international obligations that protect. ${ }^{66}$

\footnotetext{
${ }^{64}$ Idem.

${ }^{65}$ Art. 124 - To provoke abortion against yourself or to consent abortion against yourself: Sanction detention, one to three years. Abortion provoked by a third part. Art. 126 - To provoke abortion with the consent of the impregnated person: Sanction - reclusion, one to four years. Single paragraph - The same sanction from the latter article is applied if the pregnant person is not older than 14-years-old or if she suffers from mental conditions, or if the consent is obtained through fraud, grave threat or violence. Qualified figure. Art. 128 - Abortion is not punished if practiced by a doctor: Necessary abortion I - if there is no other way to save the life of the pregnant person; Abortion if impregnation is the result of rape II - if the pregnancy is the result of rape and if abortion is preceded by the consent of the pregnant person or, if unable, from the legal representative.

${ }^{66}$ Supremo Tribunal Federal. Ação Direta de Inconstitucionalidade $\mathbf{n}^{0} .5581 \ldots$
} 
Within the context of ZIKAV-infected pregnant women, the possibility of legally interrupting pregnancy is supported by Brazil's Supreme Court (STF) jurisprudence and by interpretation according to Constitution (articles 23, I, 24 and 128, I, II, from Brazil's Criminal Code). ${ }^{67}$

In the case of the ZIKAV epidemics, "pregnancy was converted into a helpless wait, similar to a permanent state of mistreatment." 68 "We are talking about nine months of helplessness and, if the future child is born with neurological disorders provoked by the congenital syndrome of the ZIKAV, it begins a long way of singular health needs and accessibility that are not guaranteed as rights". ANADEP argues that the "the situation of pregnant women diagnosed with the ZIKAV is covered by article 128, I, Brazil's Criminal Code as specific state of necessity or, under articles 23, I, e 24 from the same Code, as state of necessity as a general excuse." ${ }^{69}$

When debating interruption of pregnancy, there is a real possibility that constitutional principles collide against each other; however, life is not an absolute right and there is no superior hierarchy when comparing life and other rights. In the case of pregnant women infected by the ZIKAV, there is right to a dignified life, which presupposes the right to decide if pregnancy must go on or not, since it may cause a lot of suffering. ${ }^{70}$ On the specific case of the

${ }^{67}$ The congenital syndrome of the ZIKAV, after some gestations, causes the impossibility of other pregnancies due to the death of the embryo or of the fetus. Under these situations, the possibility of interrupting pregnancy is perfectly covered by the precedent ADPF $n^{\circ} 54$, verbis: "Abortion is crime against life. It protects potential life. Speaking of anencephaly, I reiterate, there is no possible life. According to Minister Joaquim Barbosa, when voting for the Habeas Corpus $n^{\circ} 84.025 / \mathrm{RJ}$, the fetus that suffer from anencephaly, though biologically alive since it is composed by live cells and live tissues, is legally dead; it does not profit from legal protection and, I add, it does not have legal-criminal protection. In this context, interruption of the pregnancy of an anencephalic fetus does not establish crime against life - as the behavior is not covered by the description of the crime." (STF, Arguição de Descumprimento de Preceito Fundamental $n^{\circ}$. 54, Relator Min. Marco Aurélio, Judged on 04/12/2012, Published on: DJe 30/04/2013). In: Idem.

${ }^{68}$ Idem. "Philosopher and research on disabilities, Doctor Eva Kittay, describes, in an opinion, the profound dilemmas and anguishes that ZIKAV-infected women suffer during pregnancy: though all children demand responsibility, care of children with disabilities imposes additional responsibilities. These responsibilities are not necessarily unwanted, but they represent a significant burden on the mother and on the family. I have already mentioned the eternal promise to take care, the expensive medical costs imposed by some disabilities when they represent health complications, and the fact that extra care demands, at the same time, better wages from the mother, which generally is the provider of the child. Women are, as a general rule, the ones that work more so as to pay the extra costs" In: Idem.

${ }^{69}$ Idem.

70 "(...) life is not hierarchically superior to other rights", as widely demonstrated by Minister Marco Aurélio, ADPF $\mathrm{n}^{\circ} .54$, verbis: [...] the constitutionally protected interest of the fetus can collide with other constitutionally protected rights; consequently law cannot concede absolute prevalence for life, since it would deny adequate protection to other rights. And it is exactly this vice of constitutional illegitimacy that, according to this Court, invalidates the current abortion regulation... (STF, Arguição de Descumprimento de Preceito Fundamental $\mathrm{n}^{\circ}$. 54, Reporter Min. Marco Aurélio, Judged on 
ZIKAV epidemics, marked by uncertainties, anguishes and psychological suffering for all the affected women, it is reasonable to affirm that the epidemics provoke a state of necessity for the infected women; hence, abortion is a right of the woman to protect mental health. ${ }^{71}$

Thus, article 128, I, from Brazil's Criminal Code, must be analogically applied. In addition, if one does not accept analogy with this article, "it is peremptory to conclude that ZIKAV-affected pregnant women is protected by the generic state of necessity (CP, art. 24), establishing a cause of preclusion of the illicit (CP, art. 23, I)."72 Finally, "pregnancy interruption must be authorized by a public authority when the State failed to prevent women's suffering, to prevent the mosquito eradication, when it did not provide pieces of information, when it did not promote the adequate preventive measures in the context of the epidemics; also, when it does not care about the women's and children's rights." Thus:

\begin{abstract}
Interpretation according to Constitution is an adequate measure to assure fundamental precepts when a) declaring unconstitutionality of the interpretation according to which gestation interruption for ZIKAV-infected women is criminalized by articles 124 and 126 from Brazil's Criminal Code or; b) conversely, declaring interpretation of articles 128, I-II, from Brazil's Criminal Code according to the Federal Constitution, judging constitutional the pregnancy interruption choice in favor of ZIKAV-infected women, since it is a specific preclusion case, and since it is a generic preclusion case from articles 23, I, and 24, from Brazil's Criminal Code, which establishes state of necessity with a current threat of health damage provoked by the ZIKAV epidemics and worsened by the State's negligence regarding the elimination
\end{abstract}

04/12/2012, Published on: DJe 04/30/2013)." "Furthermore, the mental health of the pregnant woman is under threat. This is exposed by Minister Marco Aurélio when he votes for the decriminalization of abortion for ZIKAV-affected women: it does not only recognize sexual and reproductive human rights, but also establishes the principle according to which "every human being has the right to enjoy the highest patterns of mental and physical health" (...). If refrained from ending such a suffering, women can develop, according to Doctor Talvane Marins de Moraes, representative of the Brazilian Association of Psychiatry *85+, "a grave psychiatric case leading to depression, disorder, posttraumatic stress and even suicidal attempts, since these women are not allowed to follow a chosen path" [86]. (...) it must be emphasized that this decision is only up to the affected woman. It is not a State's attribution the balancing of values and feelings of strictly private order. (...)." In: Idem.

71 "Doctor Ilana Löwy highlights, in her opinion (annex 17), that the recognition of the right to interrupting gestations in function of psychological suffering lived by pregnant women is a lesson from the medical history from other countries: Brazilian doctors do not have an answer for women's fears and they predict a constant growth of abnormalities related to the ZIKAV syndrome. When asked if women are authorized to recur to abortion, they usually answer that "abortion is crime". At different times and places, doctors had different attitudes in relation to women suffering, even when abortion was criminalized. There is a consensus, said in 1959 British obstetrician Bevis Brock, from St. Bartholomew Hospital, in London, that "when a pregnant woman had had rubella, she is conscious of the risks and she is ready to face them, so no one tries to convince her to accept pregnancy. But she feels unable to confront the terrible anxiety of a pregnancy if obfuscated by the fear of birthing a deaf or a blind child; hence, she must present strong convictions in order to refuse this demand". Strong convictions are also necessary - or the lack of compassion for the suffering of a pregnant woman.” In: Idem.

${ }^{72}$ Idem. 
of the vector. Hence, these are legitimate hypotheses of pregnancy interruption. $^{73}$

Bearing in mind the mental anguish over reproductive issues, the ethical duties to minimize damage and to allow choices based upon beliefs and upon the concrete capacity of every single woman, woman's choice must cover a wide variety of options that includes alternatives ranging from contraceptives to pregnancy interruption. ${ }^{74}$ The action requires, "as a consequence, suspension of police investigations, suspension of prisons in flagrant, and suspension of current processes related to pregnancy interruption when it involves ZIKAV-affected pregnant until there is definitive judgment."

\section{Conclusion}

After analyzing the compiled data from the Health Ministry and the selected bibliography, Brazil's situation about microcephaly is crystal clear: it is a "poor's disease", the kind of illness that disproportionately impacts the most impoverished classes from the poorest regions. It is also possible to apply the concept of "environmental racism", since black people are among the poorest races in Brazil. In other words, blacks suffer from the ZIKAV - and from its consequences - the most.

Finally, the ZIKAV tends to be a heavier burden for women. After giving birth, mothering microcephaly-affected babies means dealing with children whose necessities are expensive and time-consuming. Not uncommonly, those mothers lack the support of government policies and of other family members. It is actually a vicious circle, since government absence is one of the main causes of the ZIKAV, ultimately because there is no adequate water supply coverage and health assistance.

There is no sex education either the possibility of termination of pregnancy in these cases. There are reports of women being abandoned by husbands and mates who did not want to have children with disabilities. The abandonment, whether by the State or by men, increases the vulnerability of these women and children. The direct action of

\footnotetext{
73 Idem.

${ }^{74}$ DINIZ, Debora. Zika..., p.17.

${ }^{75}$ Supremo Tribunal Federal. Ação Direta de Inconstitucionalidade no ${ }^{\mathbf{0}}$ 5581...
} 
unconstitutionality that is processed in the Federal Supreme Court has not yet a date for judgment. The biomedical perspective is surely relevant; nevertheless, it is far from complete. Combating the ZIKAV demands a broader perspective, able to apprehend Brazil's complexities and inequalities. Therefore, the only way to be successful against the ZIKAV is understanding the socioeconomic roots of it.

\section{References}

CARVALHO, Layla Pedreira. Vírus ZIKA e Direitos Reprodutivos: entre as políticas transnacionais, as nacionais $\mathrm{e}$ as ações locais. Disponível em: https://portalseer.ufba.br/index.php/cadgendiv/article/view/22030/14756 Acesso em: 01 fev.2018.

DINIZ, Debora. Vírus ZIKA e mulheres. Disponível em: http://www.scielo.br/pdf/csp/v32n5/1678-4464-csp-32-05-e00046316.pdf Acesso em: 10 fev. 2018.

DINIZ, Debora. Zika: do sertão nordestino à ameaça global. Rio de Janeiro: Civilização Brasileira, 2016.

DREZETT, Jefferson; GOLLOP, Thomaz Rafael. O vírus Zika: uma nova e grave ameaça para a saúde reprodutiva das mulheres. Disponível em: http://recli.elsevier.es/pt/o-virus-zika-uma-nova/articulo/S1413208716300243/ Acesso em: 01 fev.2018.

FLEISCHER, Soraya. Segurar, caminhar e falar: notas etnográficas sobre a experiência de uma "mãe de micro" no Recife/PE. Disponível em: https://portalseer.ufba.br/index.php/cadgendiv/article/view/21983 Acesso em: 01 fev. 2018.

HELLER, Leo. Relação entre saúde e saneamento na perspectiva do desenvolvimento. Disponível em: http://www.scielo.br/pdf/csc/v3n2/7152.pdf Acesso em: 09 fev. 2018.

IBGE, Diretoria de Pesquisas, Coordenação de População e Indicadores Sociais, Pesquisa Nacional de Saneamento Básico 2000/2008. Disponível em: https://biblioteca.ibge.gov.br/visualizacao/livros/liv45351.pdf Acesso em: 02 fev. 2018.

IDH Médio dos Estados Brasileiros (Brasil 2017). Disponível em: http://www.geografiatotal.com.br/2017/09/IDH-BRASIL.html Acesso em: 06 fev. 2018.

LESSER, Jeffrey. KITRON, Uriel. A geografia social do ZIKA no Brasil. Disponível em: $\quad$ http://www.scielo.br/scielo.php?script=sci_arttext\&pid=S010340142016000300167 Acesso em: 01 fev. 2018. 
NUNES, João; PIMENTA, Denise Nacif. A epidemia de ZIKA e os limites da saúde global. Disponível em: http://www.scielo.br/pdf/ln/n98/1807-0175-ln-98-00021.pdf Acesso em: 01 fev. 2018.

PINHEIRO, Diego Alano de Jesus Pereira; LONGHI, Marcia Reis. Maternidade como missão! A trajetória militante de uma mãe de bebê com microcefalia em PE. Disponível em: $\quad$ https://portalseer.ufba.br/index.php/cadgendiv/article/download/22216/14755 Acesso em: 01 fev. 2018.

SCOTT, Russell Parry. et al. A Epidemia de ZIKA e as Articulações das Mães num Campo Tensionado entre Feminismo, Deficiência e Cuidados. Disponível em: https://portalseer.ufba.br/index.php/cadgendiv/article/view/22013 Acesso em: 01 fev. 2018.

Ministério da Saúde. Boletim Epidemiológico volume 46 n 26-2015. Disponível em: http://portalms.saude.gov.br/boletins-epidemiologicos Acesso em: 06 fev. 2018.

Ministério da Saúde. Boletim Epidemiológico volume 46 n 34-2015. Disponível em: http://portalms.saude.gov.br/boletins-epidemiologicos Acesso em: 06 fev. 2018.

Ministério da Saúde. Boletim Epidemiológico volume 46 n 37-2015. Disponível em: http://portalms.saude.gov.br/boletins-epidemiologicos Acesso em: 06 fev. 2018.

Ministério da Saúde. Boletim Epidemiológico volume 46 n 46-2015. Disponível em: http://portalms.saude.gov.br/boletins-epidemiologicos Acesso em: 06 fev. 2018.

Ministério da Saúde. Boletim Epidemiológico volume 47 n 1-2016. Disponível em: http://portalms.saude.gov.br/boletins-epidemiologicos Acesso em: 06 fev. 2018.

Ministério da Saúde. Boletim Epidemiológico volume 48 n 41-2017. Disponível em: http://portalms.saude.gov.br/boletins-epidemiologicos Acesso em: 06 fev. 2018.

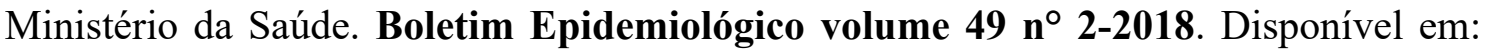
http://portalms.saude.gov.br/boletins-epidemiologicos Acesso em: 06 fev. 2018.

Supremo Tribunal Federal. Ação Direta de Inconstitucionalidade $n^{0}$. 5581. Relatora Min. Carmen Lúcia. Disponível em: http://www.stf.jus.br/portal/processo/verProcessoPeca.asp?id=310227487\&tipoApp=.pd f. Acesso em: 01 fev. 2018.

TOMAZONI, Larissa; BARBOZA, Estefânia Maria de Queiroz. Os direitos sexuais e reprodutivos na ordem jurídica internacional e o habeas corpus 124.306 no Supremo Tribunal Federal. In: PAGLIARINI, Alexandre; CLETO, Vinicius Hsu. Direito e Jurisdições: Interna e Internacional. Curitiba: Intersaberes, 2018.

VELETA, Valentina Alfredo; SOUZA, Maria Cláudia da Silva Antunes de; CORREIO, Micheline Ramos de Oliveira. Principio da participação e informação das mulheres nas tomadas de decisões ambientais em Moçambique. Disponível em: http://seer.ufms.br/index.php/revdir/article/view/3709/3302 Acesso em: 14 abr. 2018. 
WHO. ZIKA vírus. Disponível em: http://www.who.int/mediacentre/factsheets/zika/en/ Acesso em: 06 fev. 2018

** The data set for this research can be accessed on the website: Social Vulnerabilities Caused by Zika Virus Outbreak of 2015 in Brazil: Women's Health, Environmental Racism and Action of Unconstitutionality $\mathrm{N}^{\mathrm{o}}$. 5.581. November 18, 2018. Available at SSRN: https://ssrn.com/abstract=3286649 or http://dx.doi.org/10.2139/ssrn.3286649 